\title{
Analytical Support for Logistics Processes and Transport Management in Smart City
}

\author{
Chu Minh Hoang \\ Department of Traffic Police Management (Traffic Police), People's Police Academy, Hanoi, Vietnam
}

Received October 7, 2020; Revised November 12, 2020; Accepted December 22, 2020

\section{Cite This Paper in the following Citation Styles}

(a): [1] Chu Minh Hoang, "Analytical Support for Logistics Processes and Transport Management in Smart City," Civil Engineering and Architecture, Vol. 8, No. 6, pp. 1390 - 1394, 2020. DOI: 10.13189/cea.2020.080621.

(b): Chu Minh Hoang (2020). Analytical Support for Logistics Processes and Transport Management in Smart City. Civil Engineering and Architecture, 8(6), 1390 - 1394. DOI: 10.13189/cea.2020.080621.

Copyright $\mathrm{C} 2020$ by authors, all rights reserved. Authors agree that this article remains permanently open access under the terms of the Creative Commons Attribution License 4.0 International License

\begin{abstract}
Transport infrastructure of the city is evolving. It became possible to update city SMART model with use of Big Data, Data Mining and intellectual systems. It's possible to make a situational decision on the identification of transport facilities and infrastructure. Therefore, systemic analysis of the capabilities of solutions based on the paradigm "smart city" is important. In urban traffic flows, places where informal flows meet, special solutions, management measures and safety criteria are needed. Transport services analyze signals using intelligent systems, taking into account real-world situations and flow features. The purpose of the work is to study the logistics system. We are interested in them: manageability, client-orientation, optimization of cargo delivery and key logistics operations. System analysis-synthesis, decomposition and simulation, forecasting, modelling are used. The main result is a system analysis of logistics problems, object-oriented and process-oriented, functional and evolutionary. Analytical support of logistics processes has been analyzed, which makes it possible to manage logistics taking into account economic-cost and operational indicators of SMART-city. The system performance of logistics companies is classified. A system of rationing based on key indicators is proposed. This is important for designing, evaluating, selecting, planning and monitoring logistics transactions, accelerating and reducing the cost of shipping cargo and passengers. The need to audit and outsource SMART-city business processes for integration of administrative solutions and infrastructure evolution is emphasized.
\end{abstract}

Keywords Infrastructure, Flow, Analysis, System, SMART, City, Analytical Support, Transport, Logistics

\section{Introduction}

The development of digital technologies affects the life of the transport industry of any country. This includes combining flows, expanding service (e.g. customs brokers), efficient and SMART agent interactions. Logistics adaptively regulates material, information and financial-organizational flows. The development of water, air, road and railway communications is oriented to the needs of clients and logistics service [1]. It's an integral category integrating activity; it corresponds to the category "process".

The category "process" is a functionally and information-logically related sequence of works for the realization of some class of similar goals, for example, income generation in interaction with the consumer [2]. Approximately $70 \%$ of the cost of goods is determined by logistics costs. Logistics should be provided with reliable and complete information, with developed analytical support.

The city with developed transport infrastructure should be based on the digital economy and be "smart", SMART-city. SMART-Target connection: Specific, Measurable, Effective, Relative, Time bound [3].

The philosophy of "SMART-city" is necessary not only in the megalopolis, but also in the town, it will provide flexible, technological controllability with the city, its "clever" infrastructure [4]. All 5G and 3D infrastructure are connected to SMART-city.

The work carried out a system analysis of analytical 
support of the transport company, proposed methods of structural approach to analysis. The key logistic problems and approaches to their solution in the "SMART-city" paradigm are specified.

\section{Theoretical Framework}

Business considers business processes that help solve problems of trade, acquisition, transportation, marketing, investment, taxes, and cooperation with shareholders, partners, etc. These tasks can be attributed to the main processes of the business; they can be auxiliary in determining the revenues of any enterprise.

Logistics integrates short-, medium- and long-term management, operational planning [5]. Their full-length analysis requires a system review and a relevant infrastructure, and therefore an integrated indicator system. It will allow developing smart organization of regional structures and relations [6].

Logistics activates key processes:

1) service standardization;

2) order (purchase) management;

3) transport service;

4) support;

5) logistics lifecycle;

6) management of pricing (price policy and its audit);

7) allocation of resources (not only material);

8) analytical (informational) support.

In addition to these key functions, there are auxiliary functions:

1) warehouse storage (processing, including possible returns);

2) processing and ecological packing-unpacking of cargo;

3) service and logistics support;

4) collection and storage of returned wastes, etc.

An integrated, hybrid digital transport infrastructure should be adequate for all participants.

The system of analytics of transport company is based on set of the structured indicators (indicators) and analytical methods allowing making adequate assessment of logistic. Performance of the transport organization is a multifaceted and multidimensional concept [7-9].

The development of the digital economy, smart city infrastructure isn't only a current and fashion trend. Even for large transport and logistics organizations, holdings. There are also many common specific problems, such as using the Blockchain methodology. This applies to many business processes: transport operation, insurance situations, client connections and partnership relations.

Blockchain in motor vehicles can be used to store driver reports, on transport and its maintenance history of logistics, etc. The Russian Platoon system plans to use blockchain [10]. Therefore, logistics can be considered a priority application of blockchain technologies, for example, for the implementation of a global intelligent transport network based on SMART contracts [11].

The level of "digital development" of logistics is still insufficient, so logistics organizations also use traditional IT-oriented communications. For example, distributed networks that allow "digital" access and exchange with partners and clients, competitors [12].

But experts of a number of agencies (DSCI, APQC, etc.) speak about serious problems of training personnel on blockchain: only one third of logistics specialists are familiar with blockchain, $1 \%$ uses it in their logistics deliveries, and $10 \%$ think blockchain will fundamentally change logistics [9].

\section{Methodology}

Every extensive organization providing logistics services is an open and complex socio-economic system, with its purpose, structure and resources. The systemic performance of such an organization may be assessed:

1) the set of business processes (efficiency of each of them is assessed separately);

2) the execution of business functions, their contribution to target tasks;

3) the place (position) in the market, competitiveness and sustainability;

4) the precedents, comparative analytics in a similar environment.

The logistics company's digital business transformation analytics is not always well structured. But it's possible to distinguish the main groups of analyzed parameters:

1) demand group for logistics services, which is activated by market status;

1) group of economic indicators - growth rate of profit, volume, stability, profitability, etc.;

2) a group connected with the interests of employees improvement of working conditions, wages, etc.;

3) risk and reserve group (together with optimization);

4) investment group;

5) service group, etc.

For the transport company, it's necessary to assess the values of the interaction parameters and performance. This requires methods of system analysis [13], in particular analysis, decomposition, identification, etc. The analysis is influenced by uncertainty of estimates and selection of counterparties, insufficient logistics potential.

In a logistics company, it's relevant to track key actions:

1) strengthening of competitiveness;

2) growth of profit and capitalization;

3) control of resources and transportation;

4) improvement of technical and technological base;

5) application of innovative technologies and techniques of logistics, supplies, etc. 
The Logistics Analysis Service should effectively support following procedures:

1) preparation for delivery;

2) minimization of the order-delivery or order-delivery waiting cycle;

3) delivery control (type, volume, term);

4) correction (operative change) of orders;

5) prompt information on the state of the current process;

6) individual service and delivery in convenient time, place, etc.

Two evolutionary directions of business processes of the transport company are classically identified: two-level system ("order-delivery") of business processes and outsourcing. Ways such as crowdfunding, virtual infrastructure, can now be considered.

But it's possible to switch from a three-tier system of the transport company "management - agency - customer" to a two-tier system "customer - single center." Such a system is based on the principles of:

1) high level of transport service - result of control;

2) division of orders into territorial zones with even distribution of transport, logistics companies;

3) intelligent (automated, automatic) support of logistics companies.

In a two-level system, each logistics node performs all logistical activities. But the structure of relationships between companies is also changing.

The main differences of the three-level and two-level management system are both in the various steps of making management decisions and in the implementation of management impacts - from the management of the company to all departments. Efficient (in terms of time, resources, costs, professionalism of execution) solution of transport with connection of outsourcing. Key transport logistics processes are often outsourced, improving the quality, service and efficiency of their execution.

Logistics outsourcing gives transport companies the opportunity to concentrate their efforts on contracts, organizational flexibility, investment attractiveness, risks, costs, etc.

The main methods of obtaining analytical information in logistics, in our opinion (see also [13]), are:

1) analysis of organization documentation;

2) market and marketing research;

3) personnel management and their categories;

4) expert surveys of market entities (cargo owners, suppliers, forwarding agents, competitors, etc.);

5) analysis of technological connections of processes, etc.

Methods of structuring analyzed information are also extensive: classification, indicator, methods of mathematical modeling (main components, cluster and cognitive analysis, etc.). The selection of a specific method determines the content and direction of the target process evaluated in the organization.

Logistics company is shaped by labor potential and its rational use using adaptive control effects. The main analytical parameters of management can be: staffing; professionalism of personnel; stability of the team, etc.

\section{Results and Discussion}

We classify the logistics systems of the transport industry by stages, by life cycle:

1) resource flows (during transportation);

2) flows of products, services;

3) streams of finance;

4) flows of information;

5) human flows (including organizational flows);

6) cargo flows and storage;

7) service.

The development of business processes (author's table 1) of the road transport enterprise helps to solve key strategic problems and tactical problems.

Table 1. Large business processes and attributes of the transport company

\begin{tabular}{|c|c|c|c|c|}
\hline Analytics & Resources & Planning & Logistics & Flows \\
\hline \multicolumn{5}{|c|}{ Business process exit } \\
\hline $\begin{array}{l}\text { Information } \\
\text { Resources } \\
\text { Stocks }\end{array}$ & $\begin{array}{c}\text { Gain of stocks } \\
\text { Power } \\
\text { Number of transport } \\
\text { Volume }\end{array}$ & $\begin{array}{l}\text { Volume } \\
\text { Time } \\
\text { Way } \\
\text { Expenses } \\
\end{array}$ & Transportation & $\begin{array}{c}\text { Passengers } \\
\text { Freights }\end{array}$ \\
\hline \multicolumn{5}{|c|}{ Subject (object) of work } \\
\hline $\begin{array}{c}\text { Territory } \\
\text { Zone }\end{array}$ & $\begin{array}{c}\text { Tourism } \\
\text { Business streams }\end{array}$ & $\begin{array}{l}\text { Routes } \\
\text { Knots } \\
\text { Roads } \\
\end{array}$ & $\begin{array}{c}\text { Delivery and service } \\
\text { Packing, loading and unloading } \\
\text { and cargo delivery } \\
\end{array}$ & $\begin{array}{l}\text { People } \\
\text { Freights }\end{array}$ \\
\hline \multicolumn{5}{|c|}{ Business process performance evaluation criteria } \\
\hline & & $\begin{array}{r}\text { Cost } \\
\text { Safety } \\
\text { Effectiven }\end{array}$ & & \\
\hline
\end{tabular}


In transport logistics, the length of the supply chain affects customer orientation and chain link efficiency. Heuristic and intuitive controls and "control points" are often used. This does not increase the efficiency of logistics in the context of multicriterality and uncertainty of the environment, and it inhibits the maintenance of cargo flows and does not contribute to the improvement of information value and also the variety of infrastructure conditions of the organization and implementation of logistics procedures.

It's necessary to move from individual technological operations (procedures) in transport logistics to infrastructure and intelligent processes. For example, on the basis of Big Data, Data mining, Business Intelligence and Blockchian technologies $[14,15]$, as well as on the infrastructure "SMART-city" using navigation in complex systems [16].

In customer-oriented logistics, the customer isn't interested in the "empty" time of registration, loading and unloading and other internal corporate problems of the logistics company. He's interested in time, integrity, comfort of delivery and corresponding to the SCM statistical tools of management, estimation and forecasting of simulation scenarios (for example, delivery to the ordered place and time, with ordered maximum costs).

Even KPI coefficients [17] may interest him when choosing a company, as participation and efficiency of customs brokers.

The advance of freight, passenger flows on a transport network structure is often burdened by delays (delay risks) associated with uncertainties and "noises" of basic processes. The main types of key processes are "sending", "preparation-design", "landing-loading", etc.

The competitiveness of logistics companies, as well as their evolutionary (adaptation) possibility, also affects strongly. In digital logistics, this is a crucial aspect, as not everything solves a direct increase in transport fleet or technical speed. Infrastructure reengineering or even conventional modernization helps here.

You need relevant customer-oriented logistics analytics. On road transport this problem is considered by a number of authors, in particular [18] (on water transport [19] and railway transport [20]), where common terminal networks (cargo, passenger, customs and other terminals) are offered.

The standardization system offered by us is based on the following key indicators:

1) the logistic value (added value/cost of all transported freights);

2) qualitie of service, service (the total cost or volume of service of the class "VIP"/total the cost or volume of all services);

3) share in the logistics structure (number of logistics objects of the company/number of such objects by industry);

4) logistics services (point 2/summa all point 3);
5) rating position of the logistics company/region (provision of quality service of the company or region taking into account point 4 ;

6) supply of logistics infrastructure (defined similarly point 4);

7) competitiveness/competitive tension or industry density (region);

8) speed of the logistics cycle (customer service on the whole chain "A - B");

9) "capacity of niche" (logistics network "A - B")

You can evaluate the evolutionary potential of a logistics company with a production function:

$$
F(x)=\prod_{i=1}^{9}\left(\sum_{j=1}^{k_{i}} A_{j} x^{\alpha_{i}}\right)^{\beta_{i}},
$$

where $A_{i}$ - tempo coefficients by i-th indicator $x_{i}(t)$, $\alpha_{i}, \beta_{i}$ - identified coefficients. The function $\mathrm{F}(\mathrm{x})$ or $\alpha_{i}, \beta_{i}$ parameters are identified by the least squares algorithm [21].

We note the possibility of improving the competences of the employees of the logistics company on the basis of the new principles provided by the infrastructure "smart city". These are principles such as "exactly in time", "divided destiny", "positional approach", etc. For example, the latter principle involves identifying the company's current position in the market, taking into account the views of consumers, and then adjusting the development strategy.

\section{Conclusions}

Logistics, tracking digital trends, is looking for the possibility of effective application of IT in the transport business. The development of logistics, infrastructure of the city leads to the formation of virtual supply chains of business processes.

The transport company's analytical management support system will help integrate and consolidate business processes, provide single access to data (anytime, anywhere), and manage human resources to save resources (not just financial). At the same time, ERP+CRM symbiosis provides access through mobile devices and information panels. But the main advantage of analytical support is a synergistic effect, which without such support is impossible, because it's not the sum of current effects.

The design of logistics chains (formation, optimization, transportation) gives the transport enterprise opportunity to reduce internal production costs and increase its competitiveness. Logistics, tracking digital trends, is looking for the possibility of effective application of IT in the transport business. The possibilities of blockchain technologies, artificial intelligence, machine learning are actively explored. Predictive analytics is also used in the logistics flow forecast.

The studies carried out are used to forecast, improve the 
quality of business processes of logistics companies, as well as their partners and customers. Modeling taking into account the offered system of indicators (indicators) and function will allow carrying out logistic rationing and forecasting, infrastructure and functional improvement of logistics, transportations. The possibility of assessing evolutionary potential, identifying parameters of self-organization of the system, assessing the activities of both small logistics firms and transport holdings is also important.

\section{REFERENCES}

[1] O.D. Pokrovskaya. Terminalistics: general issues, Kazan: Publishing house "Buk", 142 p, 2016.

[2] M. Hammer, D. Champi. Reengineering Corporation, Manifesto of Revolution in Business, M.: Publishing House Mann, Ivanov and Ferber, 288 p, 2011.

[3] M. Eremia, L. Toma, M. Sandulac. The Smart City Concept in the 21st Century, Procedia Engineering, vol.181, pp.12-19, 2017. DOI:

https://doi.org/10.1016/j.proeng.2017.02.357

[4] M. Ablameyko S. Ablameyko. "Smart City": from theory to practice, Science and Innovation, № 6 (184), pp. 28-34, 2018.

[5] N.Y. Isakova. Interactive paradigm of enterprise integration in the context of globalization of the economy and integration of capital, Fundamental research, №10, pp. 163-167, 2013.

[6] E. Stryabkova, Yu.Lisikova, I. Chistnikova, A. Glotova, M. Cochergin. Tools for selecting the spatial development priorities of the region in the context of smart specialization, Amazonia Investiga, 8(24), pp.91-101,2019. Retrieved from: https://amazoniainvestiga.info/index.php/amazonia/article/v iew/955 (date of appeal: 28.04.2020).

[7] M.G. Grigoryan. Approaches to Evaluation of Performance of Organizations Providing Logistics Services, Prospects for Development of Logistics and Supply Chain Management: Collection of Scientific Works of the VII International Scientific Conference (April 18, 2017), Part 2, M: ES-EM Consulting, 2017, pp. 415-429. Retrieved from: https://drive.google.com/drive/folders/0B6CTNRZlWstscH RUT3hSLUg5VIU (date of appeal: 28.04.2020)

[8] G.A. Kononova. Selection of methods of balanced of transport management organization, Transport of Russia, №6, pp. 119-122, 2005.
[9] E.V. Tabachnikova. About the methods used in process of management of social stability of the enterprise of transport business, World of Economics and Management, v.16, No4, pp.131-143, 2016.

[10] M.N. Grigoriev, S.A. Uvarov. Plato system as the first step in the organization of logistics traffic management in Russia, Innovative science, № 3-1 (15), pp. 73-76, 2016.

[11] L. Grillia, M. Mazzucatob, M. Meolic, G. Scellatode. Sowing the seeds of the future: Policies for financing tomorrow's innovations. Technological Forecasting and Social Change, v.127, pp.1-7, 2018.

[12] L.D. Kapranova. Digital economy in Russia: state and prospects of development, Economics. Taxes. Right, No2, pp.58-69., 2018. DOI:10.26794/1999-849X-2018-11-2-5869.

[13] V.M. Kaziev. Introduction to analysis, synthesis and modeling of systems, Laboratory of buildings, 2nd ed., 244 p, 2007.

[14] Y. Yuan, F. Wang. Towards Blockchain-based Intelligent Transportation Systems, Intelligent Transportation Systems (ITSC), IEEE 19th International Conference on, IEEE. 2016: pp. 2663-2668.

[15] D.E. Namiot, O.N. Pocusayev, O.P. Kupriyanovsky, A.V. Akimov. Applications blockchain on transport, International Journal of Open Information Technologies, vol.5, № 12, pp.130-133, 2017.

[16] I.V. Besudnov, D.V. Lande, A.A. Snarsky. Internetics. Navigation in complex systems: models and algorithms, M.: Libron, 264 p, 2009.

[17] V. Kaziev, N. Tyutrin, F. Khizbullin, V. Takhumova, L. Medvedeva. Improvement and modeling of the company's activity based on the innovative KPI system, J. Fundam. Appl. Sci., 10(5S), pp. 1406-1415, 2018. DOI: http://dx.doi.org/10.4314/jfas.v10i5s.117

[18] N.N. Kalmykov, A.N. Romantsov, O.M. Trofimov, S.A. Makovkin, M.S. Fadeev. Study of the main problems in the field of passenger transport and transport, Transport Business in Russia, №4, pp.103-105, 2017.

[19] V.E. Marley, E.S. Fedorina. Analysis and processing of data flows in the information system of the port, Journal of the State Institute of Maritime and River Fleet named after S.O. Makarov, №2 (37), Pp. 227-232, 2016.

[20] O.B. Malikov, O.D. Pokrovskaya. Analysis of regulation system in railway transport from logistics and client orientation, News of PGUPS, №2. pp.187-199, 2017.

[21] Econometrics: textbook, The 2nd prod. Under Ed. Eliseyeva I.I., M: Finance and statistics, 576 p, 2006. Recovered from: https://institutiones.com/download/books/1224-ekonometri ka.html (date of appeal: 28.04.2020). 